\title{
Bibliographic Analysis of Basic Leadership Models in a Global Environment
}

\author{
Ivan Miloloža
}

The Josip Juraj Strossmayer University of Osijek, Faculty of Dental Medicine and Health, Croatia

\begin{abstract}
Leadership is one of the functions of management, and unlike other management functions, it cannot be partially transferred to others, so leadership becomes the most important and real function of management. It is a ubiquitous and current topic because successful leadership is a skill that is present in different aspects of life and organizations, such as in a company, the state, in wars, or within the family. The art is to influence other people and relationships so that they are willing to achieve set goals. Leadership is an action, not a position that is automatically gained by a position in an organization. The phenomenon of leadership and successful leaders always capture the attention of not only the scientific but also the social public. Given the large number of studies conducted and studies written on the importance and the impact of leadership, numerous models, approaches, and leadership theories have been formed. The paper aims to shed some light on the research trends of leadership types in scientific literature. The Scopus database has been researched using the keywords "leadership type", which resulted in 127 journal articles. A bibliographic analysis has been conducted with the focus on the timeline of publications, trends in leading authors, institutions, and countries, and the financing institutions analysis. Citation analysis has also been conducted with the focus on papers with the highest number of citations. Topics of the papers have been analyzed using the text mining analysis, which revealed a variety of management-related topics.
\end{abstract}

Keywords: leadership, leadership research, international environment, globalization, polyvalence of the leadership phenomenon

JEL classification: 015

Paper type: Research article

Received: Sep 02, 2021

Accepted: Sep 25, 2021

DOI: 10.54820/AXEH6325 


\section{Introduction}

Leadership is having the power to achieve what you want. The essence is the relationship between people in the organization, ie gaining members of the organization, and not every manager can do that, but only the one who has the characteristics and qualities of a leader. Leadership can never be learned to the end, it takes something charismatic in personality. The key to today's successful leadership is influence, not authority.

Leaders are people who do the right things (Carnell, 1990), and to do so, they must have a clear vision, knowledge, and the ability to conceptualize. The definition of leadership is as much as the theorists who have been engaged in researching it. Fiedler cites 12 definitions, McGregorova and Burns in the book Leadership mention 130 of them while Bennis and Nanus collected 200 (Sikavica et al., 2008). Leadership can be defined as the mutual influence applied to a situation and through a communication process directed toward achieving a specific goal (Tannenbaum et al., 1961). Leadership is a set of behaviors that are influenced or determined by culture and one's life experience (Megginson et al., 1995).

Leadership is the influence, art, or process of influencing people in such a way that they strive to achieve the goals of the group with satisfaction and enthusiasm (Koontz et al., 1988). According to Hemphill and Coons, leadership is the behavior of individuals who direct activities and the group toward a common goal (Hemphill et al., 1957). Leadership is the force that chooses our dreams and determines our goals, the driving force of success (Schuller, 1987). Leadership is a social process that involves setting goals for a particular group, motivating behavior to explore goals, influencing group thinking and behavior (Denton, 1998). Leadership can be identified with the character of the hero with qualities such as intelligence, energy, style, sacrifice ith. (Cleland, 1989). David says leadership is part of management, but not the whole. Leadership is the ability to convince others to pursue goals. It is the human factor that connects and motivates the group (David, 2005). Leadership is an individual characteristic, a way of behaving, influencing other people, a relationship with other people (Conger, 1992).

Leadership is the process of using non-coercive influence to shape the goals of a group and organization, motivating behaviors that lead to achieving goals, and helping to define the cultures of the group or organization. Leadership as a trait is a set of characteristics for marking that person who presents himself as a potential leader (Jago, 1982). Price defines leadership as setting direction and motivating people by the power of their personality (Price, 2004). Leadership is the process of influencing a leader and followers to achieve an organization's goals through change (Lussier et al., 2004). Leadership is the side that has the power to force another to do something they would not otherwise do (Dahl, 1957).

The purpose of this work is to put more focus on leadership research trends in scientific literature. The keywords "leadership type" were searched in the Scopus database, resulting in 127 journal articles. The emphasis of the bibliographic analysis was on the timeline of publications, trends in major authors, institutions, and nations, and the examination of financial institutions. Citation analysis was also carried out with a focus on the papers with the most citations. The articles' subjects were examined using text mining, which revealed a wide range of management-related topics.

\section{Global leadership skills}

In the modern world of work, three new types join physical and financial capital: human capital in the form of all the skills, knowledge, experience and char, 
acteristics of individuals; social capital as a network of contacts that enables the dissemination of information and the transmission of norms; Intellectual capital in response to growing demands to adapt to technological advances and constant change in the business world. Intellectual capital represents knowledge in the form of a dynamic process through human resources, with the purpose of transformation and value creation for organizations (Kolaković 2003). Successful international leaders can only be globally aware individuals because they understand and influence associates whose attitudes, values, and ways of working differ from their own. Today, in a dynamic and unpredictable global world, new leaders are needed who can be flexible and savvy enough to provide valid answers for challenging times. New leaders are coming for the new century, warrior leaders who are replacing tired managers of the industrial age (Lauren, 2000). At the beginning of the 21 st century, a significant impact and growth of intercultural cooperation was felt, which was greatly contributed by transport connections and the faster and more advanced development of information and communication technologies (LloydWalker et al., 2011). A leader in the 21 st century must possess the skills that will enable him to effectively and successfully lead teams from different countries and coordinate their work. Intercultural skills and abilities are necessary to be able to function successfully in an international global environment. Some of the required skills and abilities of international leaders are as follows: professional and technical knowledge of primary processes within the organization, emphasized teamwork and understanding of interpersonal relationships, understanding company strategy and its implementation internationally, international work experience (Tetenbaum et al., 2011 ). It is necessary to understand several complex and interrelated factors to make the best possible use of all opportunities, but also to overcome the threats that the company may face. Organizing implies a predefined way of using all resources within the company, while the factors that affect the success of companies and managers in the international environment (Bahtijarević-Šiber et al., 2008):

- Economic factors - developed economic system and infrastructure and sources of natural resources are the basic economic factors that contribute to a more successful business;

- Legislative factors - local laws and regulations can greatly complicate business, companies must know the local laws relating to a property, commercial law, patent protection, workers' rights;

- Political factors - the political system, political stability, and political risk are the basic political factors, but in addition to them it is necessary to monitor various factors such as indices of competitiveness, corruption, economic freedoms;

- Socio-cultural factors - different local customs, values, attitudes, norms, moral principles, attitudes towards work, but also demographic factors can greatly complicate doing business within a country, especially if the company is not willing to accept and do business within the country.

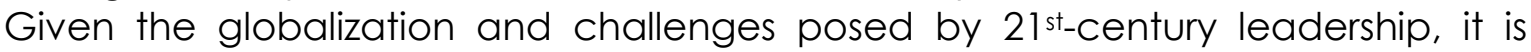
extremely difficult to find a person who has all the qualities and qualities of a successful leader and who can lead intercultural teams and guide them toward executing a business strategy. Intercultural skills and abilities are needed today by both leaders and associates to be able to function successfully in an international environment. There are great political influences of global institutions as well as regional integration, and they then define the career direction portfolio. All of these challenges need to be overcome and it is difficult to find a person who is capable of leading intercultural teams. Multinational companies make great efforts to find quality employees and train them to work (Farndale et al., 2007). Positive impact on 
employees is much more difficult to achieve in multinational companies than in domestic ones (Foss et al., 2012). Some of the problems faced by multinational companies in relation to domestic ones are the distance of individual branches, which makes it difficult to directly control the business, which can be improved by using advanced information and communication technologies. People who are not sensitive to cultural differences cannot be successful leaders because they cannot adapt to emerging cultural differences (Bhawuk et al., 1992). Corporate culture is one of the main factors contributing to the impact on employees, primarily thinking about the customs, attitudes, habits, skills, education of employees (Nguyen et al., 2014).

The research project GLOBE 2020 - Global Leadership and Organizational Behavior Effectiveness was founded by Robert House in 1991. For more than 30 years he has been researching three different but interrelated topics: social culture, leadership, and organizational practice. More than 1,700 managers from 900 corporations from over 60 countries participated in the survey. and thus became one of the largest and most comprehensive studies in the field of social sciences. According to the research, Globe singled out nine dimensions of culture: performance orientation, future orientation, self-confidence, a distance of power, humanity, institutional collectivism, collectivism within the group, avoidance of insecurity, and gender equality. The Globe also lists six characteristics of international leadership: charismatic leadership, team orientation, participation, human orientation, autonomy, and self-preservation (GLOBE, 2020).

\section{Methodology}

A bibliographic analysis of papers on leadership within the Scopus database was performed using the keywords "leadership type", which resulted in 127 journal articles, 154 documents containing the term vision in the title, abstract, or keywords. Given a large number of studies conducted and studies written on the importance and impact of leadership, several leadership models, approaches, and theories have been formed. The paper aims to shed light on research trends of leadership types in the scientific literature. The bibliographic analysis was conducted with an emphasis on the time frame of publication, trends in leading authors, institutions, and countries, and an analysis of financial institutions. A citation analysis was also conducted with an emphasis on the papers with the largest number of citations. The topics of the papers were analyzed using text mining analyses that are related to the base topic. There is also an overview of the 20 most cited papers published on leadership and division according to the categories of selected words and related topics.

\section{Table 1}

Scopus search results about the research papers that investigate leadership types

\begin{tabular}{lll}
\hline Search command in Scopus & Search strategy & Number of results \\
\hline $\begin{array}{l}\text { TITLE-ABS-KEY ("leadership } \\
\text { type") }\end{array}$ & $\begin{array}{l}\text { Any document that } \\
\text { contained the phrase } \\
\text { "leadership type" in the title }\end{array}$ & \\
& or abstract or keywords. & \\
TITLE-ABS-KEY ("leadership & Search limited to the & 127 document results \\
type") AND (LIMIT-TO & documents published in a & \\
(DOCTYPE, "ar")) & journal article & \\
\hline
\end{tabular}

Source: author's work 


\section{Results}

When looking at the number of scientific papers published annually, it is divergent that this topic became more interesting after 2005 and especially relevant after 2018 (Figure 1). In the period around 2010, there is a decline, which can be attributed to the consequences of the global financial crisis beginning in late 2008. which took on global proportions and shook the world economy. After the recovery, this topic is again revealed as current.

Figure 1

Number of research papers that investigate leadership types published per year

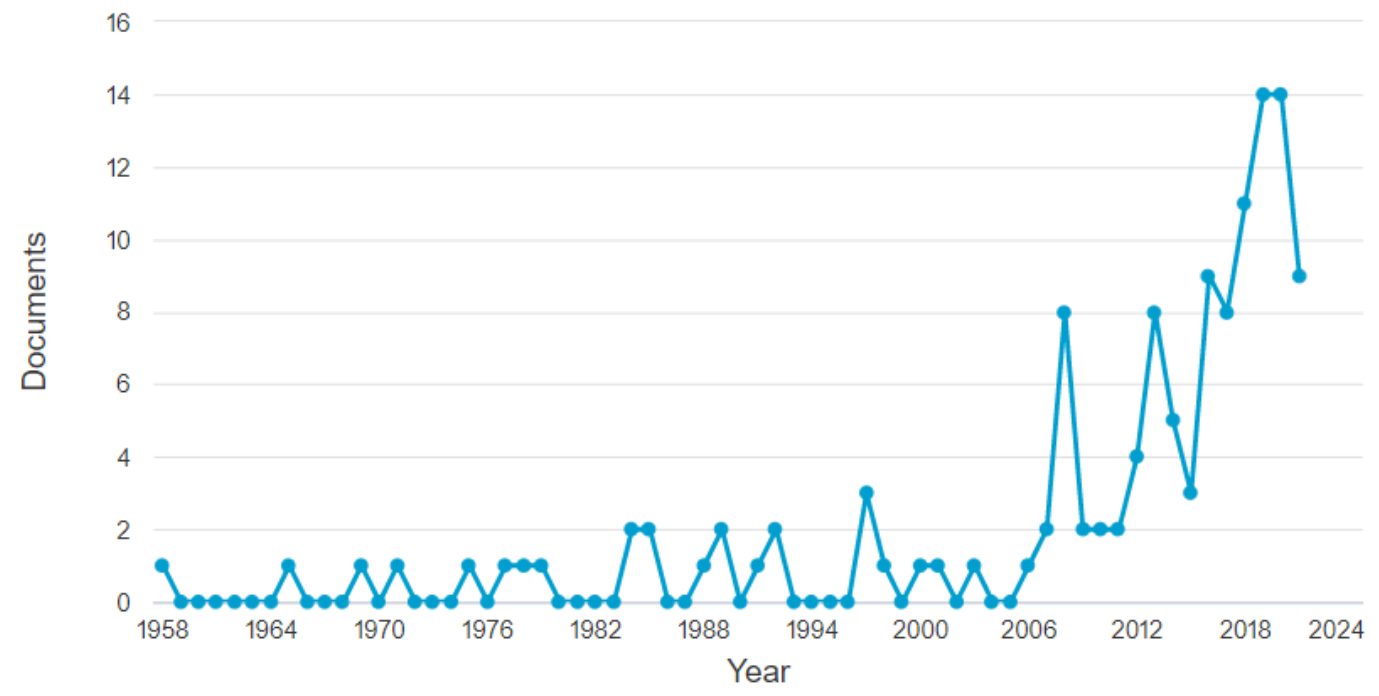

Source: author's work

Countries, according to the number of research papers, are dominated by the USA (Figure 2). Otherwise, the gap between the USA is in the intensity of research and development compared to others, which reflects the invested resources. The US is the "pure" type of immigration country where all the intellectual elite is concentrated. North Korea is improving an equally dominant number of papers on the subject, which can be attributed to the political environment that prevails in that country.

Figure 2

Country of origin of the authors of the research papers that investigate leadership

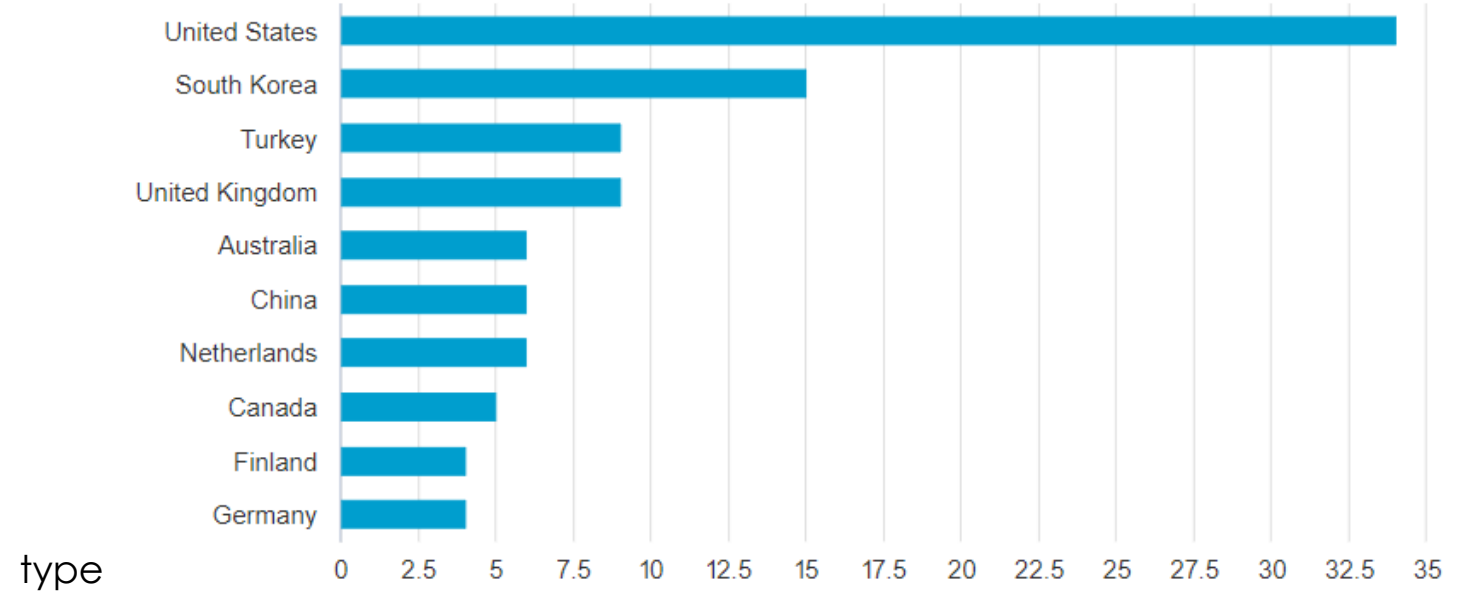

Source: author's work 
According to Pennsylvania State University which has a century-old tradition, while on the other hand Hanseon was founded in 1991 while Sangmyung University was founded between the two world wars. The tradition of existence is not a condition for success in qualitative and quantitative scientific research work (Figure 3).

Figure 3

Affiliation of the authors of research papers that investigate leadership types

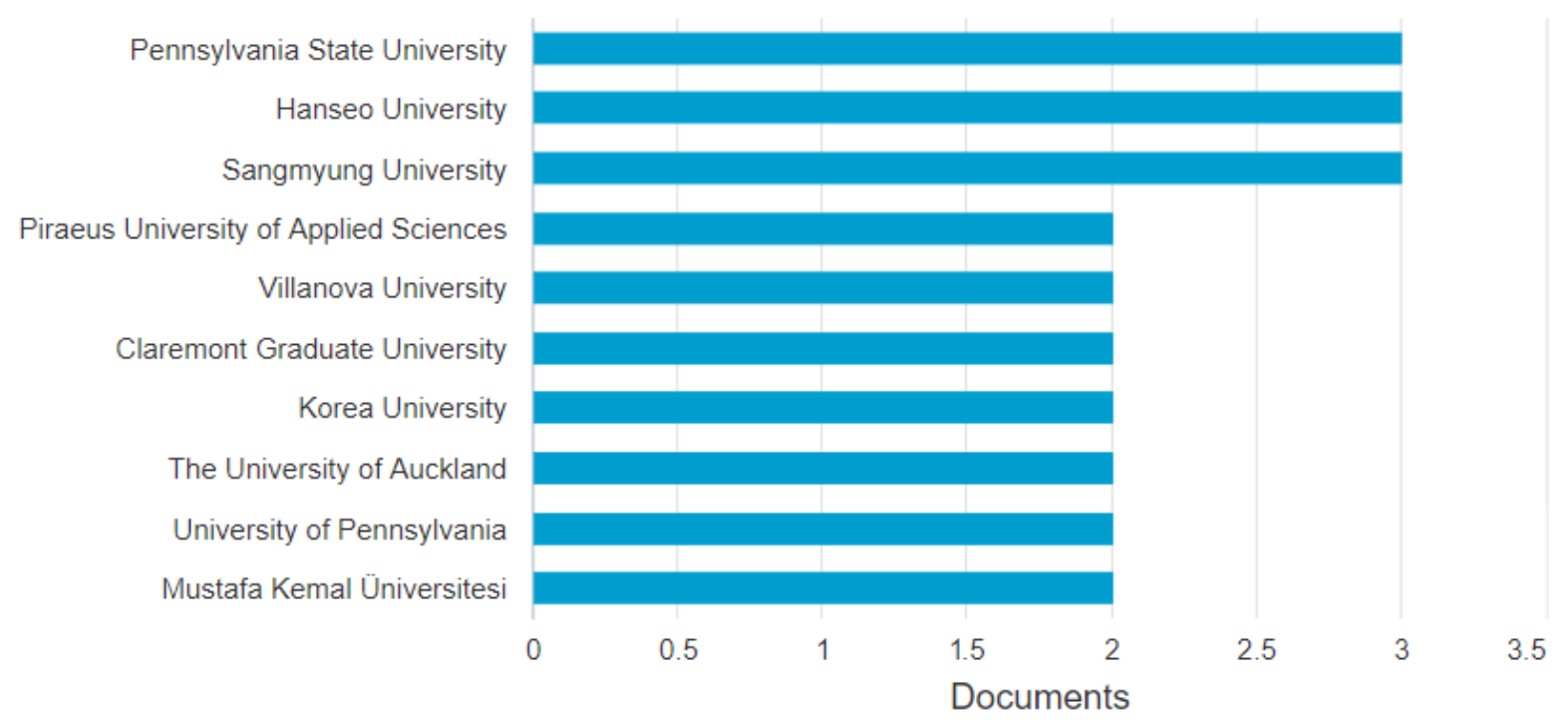

Source: author's work

As expected, the field of research of scientific papers that is at the forefront is the social sciences, namely the fields of sociology, economics, and psychology (Figure 4).

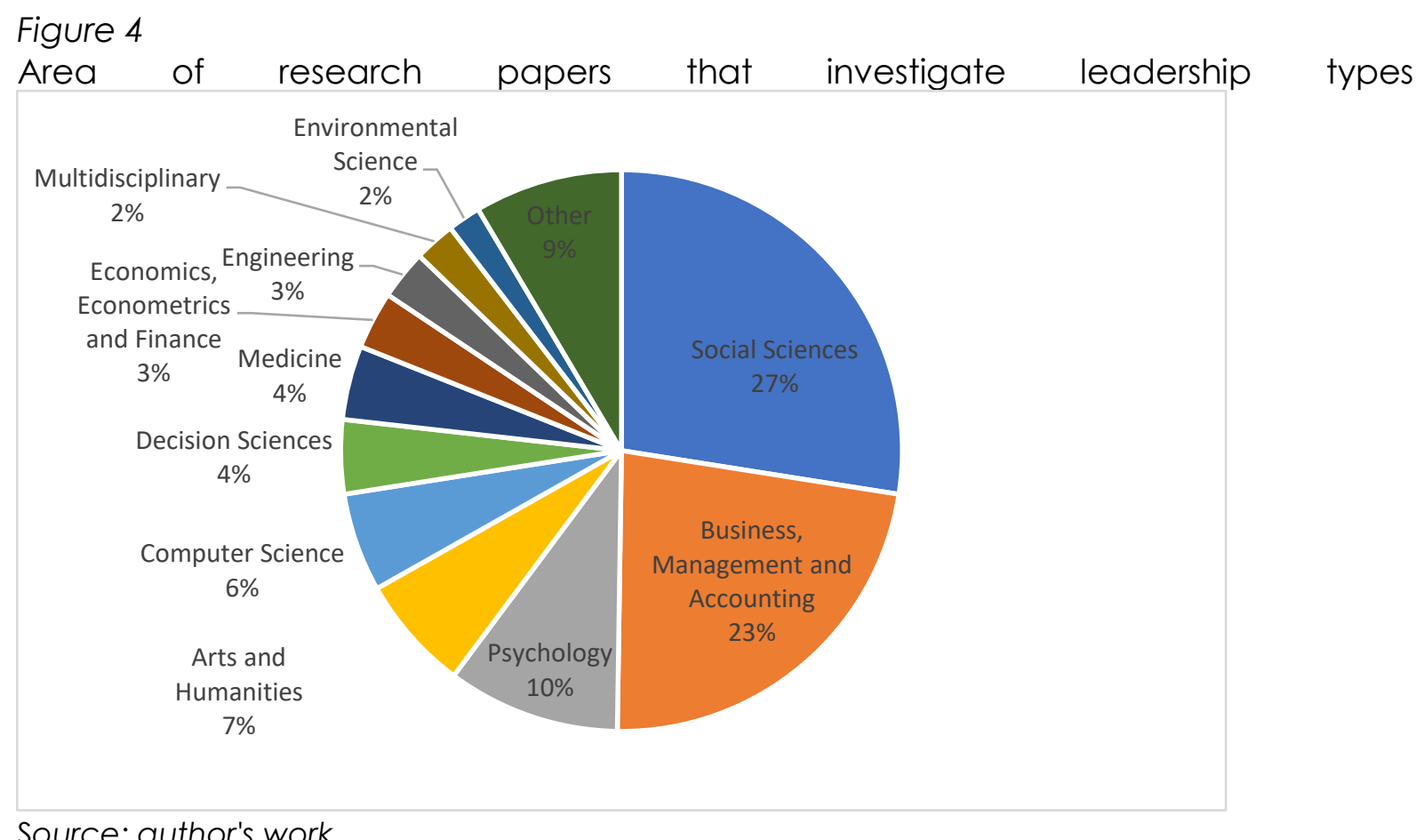

Source: author's work 
Division according to agencies and institutes engaged in research work on the topic of leadership. Most were invested, interestingly not in the USA but China (Figure $5)$.

Figure 5

Funding agency of the research papers that investigate leadership types

National Natural Science Foundation... Australian Research Council British Academy Departamento Administrativo de Cie... Department of Education and Training Department of Health, Australian Go. Fundação para a Ciência e a Tecnol... Humanities and Social Science Fund. Instituto Tecnológico y de Estudios S.

KU Leuven

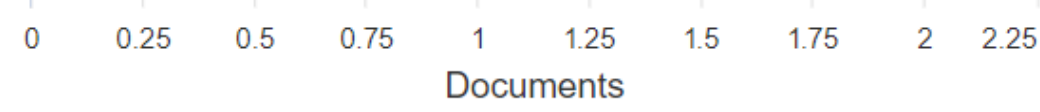

Source: author's work

Quotes from scientific papers exploring the topic of leadership from 2006 to July 2021 improve the ever-growing curve with the dominant last year (Figure 6). This speaks in favor of the thesis that extends in this paper, and that is the constant characteristic of the topic.

Figure 6

Citations of the papers research papers that investigate leadership types from 2006 to July 2021.

500

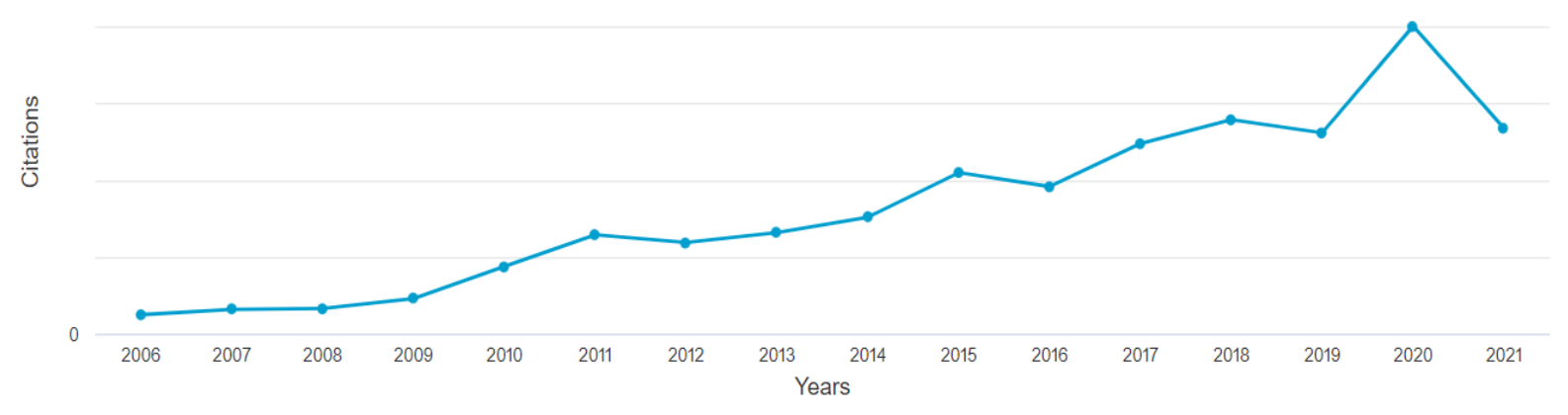

Source: author's work

Table 2 presentation of the 20 most cited papers published in research papers on leadership is the analytical ones and a review of the historical development of leadership theory. 
Table 2

The 20 most cited papers published research papers that investigate leadership types

\begin{tabular}{|c|c|c|c|}
\hline Paper title & $\begin{array}{l}\text { Publication } \\
\text { year }\end{array}$ & $\begin{array}{l}\text { Number } \\
\text { citations }\end{array}$ & of \\
\hline $\begin{array}{l}\text { The impact of leadership on student outcomes: An analysis of } \\
\text { the differential effects of leadership types }\end{array}$ & 2008 & & 894 \\
\hline $\begin{array}{l}\text { Transactors, transformers and beyond: A multi-method } \\
\text { development of a theoretical typology of leadership }\end{array}$ & 2003 & & 164 \\
\hline The role of values in servant leadership & 2001 & & 156 \\
\hline $\begin{array}{l}\text { The performance-maintenance (PM) theory of leadership: } \\
\text { Review of a Japanese research program }\end{array}$ & 1985 & & 116 \\
\hline $\begin{array}{l}\text { Home-region focus and performance of family firms: The role of } \\
\text { family vs non-family leaders }\end{array}$ & 2011 & & 114 \\
\hline $\begin{array}{l}\text { Development of outstanding leadership: A life narrative } \\
\text { approach }\end{array}$ & 2008 & & 100 \\
\hline $\begin{array}{l}\text { Attribution of Influence and Charisma to the Leader: The } \\
\text { Romance of Leadership Revisited }\end{array}$ & 1992 & & 83 \\
\hline $\begin{array}{l}\text { Presidential charismatic leadership: Exploring the rhetoric of } \\
\text { social change }\end{array}$ & 2008 & & 83 \\
\hline $\begin{array}{l}\text { Identifying early adopters of new IT products: A case of } \\
\text { Windows } 95\end{array}$ & 1998 & & 76 \\
\hline $\begin{array}{l}\text { Effectiveness of physical activity interventions for preschoolers: } \\
\text { A meta-analysis }\end{array}$ & 2013 & & 64 \\
\hline $\begin{array}{l}\text { When does procedural fairness promote organizational } \\
\text { citizenship behavior? Integrating empowering leadership types } \\
\text { in relational justice models }\end{array}$ & 2009 & & 60 \\
\hline $\begin{array}{l}\text { When should a leader be directive or empowering? How to } \\
\text { develop your situational theory of leadership }\end{array}$ & 2012 & & 60 \\
\hline Biases in appraisals of women leaders & 1997 & & 51 \\
\hline $\begin{array}{l}\text { Conditions of problem-solving and the performance of } \\
\text { charismatic, ideological, and pragmatic leaders: A } \\
\text { comparative experimental study }\end{array}$ & 2008 & & 48 \\
\hline $\begin{array}{l}\text { Cross-selling performance in complex selling contexts: An } \\
\text { examination of supervisory- and compensation-based controls }\end{array}$ & 2014 & & 45 \\
\hline $\begin{array}{l}\text { Gender, leadership orientation, and effectiveness: Testing the } \\
\text { theoretical models of Bolman \& Deal and Quinn }\end{array}$ & 2000 & & 42 \\
\hline $\begin{array}{l}\text { Leadership qualities in the return to work process: A content } \\
\text { analysis }\end{array}$ & 2008 & & 40 \\
\hline Learning leadership skills in a simulated business environment & 2012 & & 38 \\
\hline $\begin{array}{l}\text { The European Council, the Council, and the Member States: } \\
\text { changing environmental leadership dynamics in the European } \\
\text { Union }\end{array}$ & 2019 & & 30 \\
\hline $\begin{array}{l}\text { Asymmetric relationships with symmetric suppliers: Strategic } \\
\text { choice of supply chain price leadership in a competitive } \\
\text { market }\end{array}$ & 2017 & & 28 \\
\hline
\end{tabular}

Research by keywords and synonyms of research papers that explore types of leadership (Figure 7). Wordcloud of words appearing in abstract and keywords of the research papers that investigate leadership types is presented. Text razor has been used for developing the categories and topics of the extracted papers. 
Figure 7

Wordcloud of words appearing in abstract and keywords

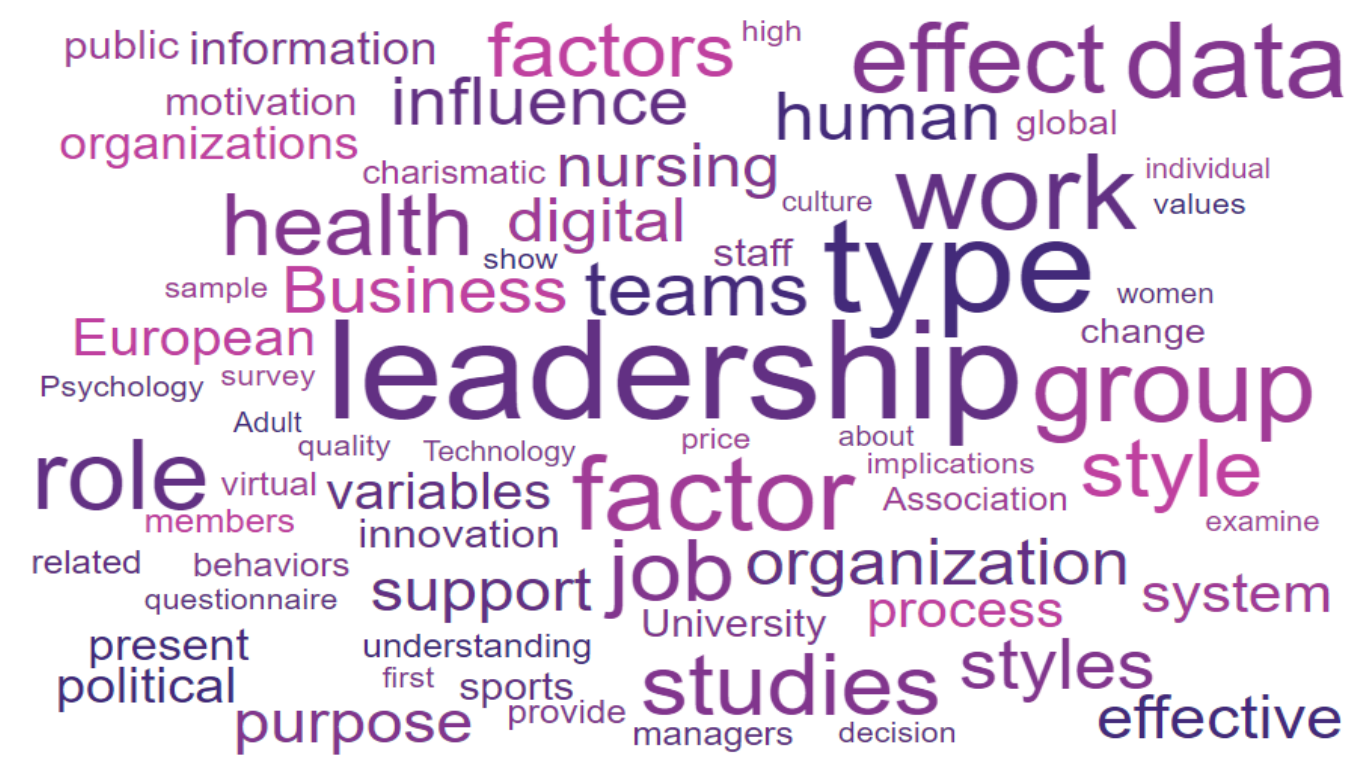

Source: author's work

Source:

Division according to the categories of isolated words that are often used in exploring leadership topics (Table 3).

Table 3

Categories extracted by Text razor tool of research papers that investigate leadership types

\begin{tabular}{ll}
\hline CATEGORIES & Category index \\
\hline education & 0.74 \\
health & 0.73 \\
science and technology>social sciences>psychology & 0.72 \\
science and technology & 0.72 \\
labor & 0.66 \\
labor>employment & 0.66 \\
economy, business, and finance>business information>human resources & 0.66 \\
science and technology>social sciences & 0.62 \\
education>school>further education & 0.60 \\
environment & 0.60 \\
\hline
\end{tabular}

Source: author's work

Research-based on the 100 most influential topics that are most often used in research papers on the topic of leadership and these are statistical, managerial, organizational topics and those applicable categories as related topics (Table 4). 
Table 4

The 100 strongest topics extracted by Text razor tool of research papers that investigate leadership types

\begin{tabular}{|c|c|c|c|c|}
\hline $\begin{array}{r}\text { Agent-based } \\
\text { model }\end{array}$ & Data analysis & Governance & $\begin{array}{r}\text { Occupational } \\
\text { safety and } \\
\text { health }\end{array}$ & $\begin{array}{r}\text { Shared } \\
\text { leadership }\end{array}$ \\
\hline $\begin{array}{r}\text { Applied } \\
\text { psychology }\end{array}$ & Database & $\begin{array}{r}\text { Group } \\
\text { dynamics }\end{array}$ & $\begin{array}{r}\text { Organization } \\
\text { climate }\end{array}$ & Simulation \\
\hline $\begin{array}{r}\text { Attitude } \\
\text { (psychology) }\end{array}$ & Decision-making & Happiness & Organization & $\begin{array}{r}\text { Social } \\
\text { competence }\end{array}$ \\
\hline Behavior & $\begin{array}{r}\text { Dependent and } \\
\text { independent } \\
\text { variables }\end{array}$ & $\begin{array}{l}\text { Higher } \\
\text { education }\end{array}$ & $\begin{array}{r}\text { Organizational } \\
\text { commitment }\end{array}$ & $\begin{array}{r}\text { Social } \\
\text { enterprise }\end{array}$ \\
\hline $\begin{array}{r}\text { Behavioural } \\
\text { sciences }\end{array}$ & $\begin{array}{r}\text { Digital } \\
\text { transformation }\end{array}$ & Human & $\begin{array}{r}\text { Organizational } \\
\text { culture }\end{array}$ & $\begin{array}{r}\text { Social } \\
\text { psychology }\end{array}$ \\
\hline Big data & Economics & Human nature & Personality & Social support \\
\hline Business & Economy & $\begin{array}{r}\text { Human } \\
\text { resource } \\
\text { management }\end{array}$ & Personality type & Sociology \\
\hline Charisma & Education & Information & Politics & Software \\
\hline Cognition & Emotion & $\begin{array}{r}\text { Information } \\
\text { system }\end{array}$ & Pragmatism & Statistics \\
\hline $\begin{array}{r}\text { Cognitive } \\
\text { science }\end{array}$ & Empathy & Innovation & Price & Supply chain \\
\hline $\begin{array}{r}\text { Collaborative } \\
\text { learning }\end{array}$ & $\begin{array}{r}\text { Employee } \\
\text { engagement }\end{array}$ & $\begin{array}{r}\text { Job } \\
\text { performance }\end{array}$ & Productivity & $\begin{array}{l}\text { Supply chain } \\
\text { management }\end{array}$ \\
\hline Communication & $\begin{array}{r}\text { Employee } \\
\text { motivation }\end{array}$ & Job satisfaction & $\begin{array}{r}\text { Psychological } \\
\text { concepts }\end{array}$ & Sustainability \\
\hline Community & Employee retention & Leadership & $\begin{array}{l}\text { Psychological } \\
\text { resilience }\end{array}$ & Teacher \\
\hline $\begin{array}{r}\text { Competence } \\
\text { (human } \\
\text { resources) }\end{array}$ & Employment & Leadership style & Psychology & Team \\
\hline $\begin{array}{l}\text { Competition } \\
\text { (economics) }\end{array}$ & Empowerment & Learning & $\begin{array}{r}\text { Qualitative } \\
\text { research }\end{array}$ & Text mining \\
\hline $\begin{array}{r}\text { Conflict } \\
\text { management }\end{array}$ & Engineering & Management & $\begin{array}{r}\text { Quantitative } \\
\text { research }\end{array}$ & $\begin{array}{r}\text { Transactional } \\
\text { leadership }\end{array}$ \\
\hline $\begin{array}{r}\text { Contingency } \\
\text { theory }\end{array}$ & Entrepreneurship & $\begin{array}{r}\text { Market } \\
\text { (economics) }\end{array}$ & Reinforcement & $\begin{array}{l}\text { Transformatio } \\
\text { nal leadership }\end{array}$ \\
\hline $\begin{array}{r}\text { Core self- } \\
\text { evaluations }\end{array}$ & Experiment & Millennials & Self-control & $\begin{array}{r}\text { Turnover } \\
\text { (employment }\end{array}$ \\
\hline Culture & Factor analysis & $\begin{array}{r}\text { Millennium } \\
\text { Development } \\
\text { Goals }\end{array}$ & Self-efficacy & Virtual team \\
\hline Data & Game theory & Motivation & $\begin{array}{r}\text { Servant } \\
\text { leadership }\end{array}$ & Well-being \\
\hline
\end{tabular}

Source: author's work

\section{Conclusion}

Leadership is studied through the theory of management which is a relatively young science and much is theorized about this topic which is always current. By synthesizing definitions of leadership we can consider it as a process and as an individual trait, a combination of personal qualities and skills that allows us to raise enthusiasm, cohesiveness, and effectiveness in our co-workers while other people in 
the same situation cannot achieve such results. Leadership is not a characteristic of an individual in isolation but a group interrelationship especially today when we live in a global world of unstable times of rapid change. It is an intense interaction towards the achievement of set goals and through it, the leadership of a person and that person as a leader is recognized. In doing his job, the leader is in different roles. Equally, there are different styles and models of leadership, which are then adjusted according to the specific situation. The new leaders have the intercultural worldview and skills necessary to function successfully in an international global environment. For a leader to be a leader, he must be at the forefront of learning by the challenges of today, so the leader is a student and a teacher, and an architect of the organization's activities. In addition to the interpersonal, there is also a technical component, which is quality, efficiency, and productivity. Research is focused depending on the situation and the direction, perspective, or paradigm of leadership. Not all theories to date have spawned the best leadership style, but have only been upgraded to previous ones. Every leader is unique, unique, and unrepeatable just like the environment and the people in it, and all theories should be viewed in context. Leadership theories are like a concentric circle where each new theory is a circle with a larger diameter within which there are circles with smaller diameters, ie previously defined theories.

\section{References}

1. Bahtijarević-Šiber, F., Sikavica, P., Pološki-Vokić, N. (2008), Suvremeni menadžment: Vještine, sustavi i izazovi, Školska knjiga, Zagreb.

2. Bhawuk, D. P. S., Brislin, R. (1992), "The measurement of intercultural sensitivity using the concepts of individualism and collectivism", International Journal of Intercultural Relations, Vol. 16 No. 4, pp. 413-436.

3. Carnell, C. A. (1990), Managing Chane in Organizations, Prentice Hall, New York.

4. Cleland, D. I. (1989), Project Management: Statistic Design and Implementation, TAB Books Blve Ridge Summit.

5. Conger, J. A. (1992), Learning to Lead, Jossey-Bass, San Francisco.

6. Dahl, R. A. (1957), "The Concept of Power", Behavioral Science, Vol. 2 No. 3, pp. 201-215.

7. David, F. R. (2005), Strategic Management: Concept \& Cases, Pearson Education, Upper Saddle River.

8. Denton, J. (1998), Organization Learning and Effectiveness, Routledge, London.

9. Farndale, E., Paauwe, J. (2007), "Uncovering competitive and institutional drivers of HRM practices in multinational corporations", Human Resource Management Journal, Vol. 17 No. 4, pp. 355-375.

10. Foss, I., Holme, I. M. K., Bahr, R. (2012), "The prevalence of low back pain among former elite cross-country skiers, rowers, orienteerers, and nonathletes: a 10-year cohort study", American Journal of Sports Medicine, Vol. 40 No. 11, pp. 2610-2616.

11. GLOBE (2020), "An overview of the 2004 study: Understanding the Relationship Between National Culture, Societal Effectiveness and Desirable Leadership Attributes", available at: https://globeproject.com/study_2004_2007 (1 October 2021)

12. Hemphill, J. K., Coons, A. E. (1957), "Development of the Leader Behavior Description Questionnaire", in Stogdill, R. M., Coons, A. E. (Eds.), Leader behavior: Its description and measurement, Bureau of Business Research, Columbus, Ohio State University.

13. Jago, G. (1982), "Leadership: Perspective in Theory and Research", Management Science, Vol. 28 No. 3, pp. 315-336.

14. Kolaković, M. (2003), Teorija intelektualnog kapitala, Ekonomski fakultet Sveučilišta u Zagrebu, Zagreb.

15. Koontz, H., Weihrich, H. (1988). Management, New York, McGraw-Hill

16. Lauren, W. (2000), Lean Leadership: From Chaos to Carrots to Commitment, Tower 2 Press.

17. Lloyd-Walker, B., Walker, D. (2011), "Authentic leadership for 21 st century project delivery, International Jurnal of Project Management", available at: 
https://www.semanticscholar.org/paper/Authentic-leadership-for-21st-century-projectLloyd-Walker-Walker/56c6d161 blc837c8b93019784670e1ffbd19bd6d (1 October 2021)

18. Lussier, R. N., Achua, C. F. (2004), Leadership - Theory, Application, Skill Development, South-Western, Mason.

19. Megginson, L. C., Franklin, G. M., Byed, M. J. (1995), Human Resource Management, Dame, Houston.

20. Nguyen, T. D., Aoyama, A. (2014), "Corporate culture and the adverse impact of cultural differences on technology transfer", International Journal of Technology Transfer and Commercialisation, Vol. 12 No. 1/2/3, pp. 22-42.

21. Price, A. (2004), Ready to Lead?, Jossey-Bass, San Francisco.

22. Schuler, R. S. (1987), Personnel and Human Resource Management, West Publishing Company, St. Paul.

23. Sikavica, P., Bahtijarević-Šiber, F., Pološki Vokić, N. (2008), Temelji menadžmenta, Školska knjiga, Zagreb.

24. Tannenbaum, R. J., Weschler, I. R., Massarik, F. (1961), Vodstvo i organizacija: Pristup znanosti o ponašanju, McGraw-Hill.

25. Tetenbaum, T., Laurence, H. (2011), "Leading in the Chaos of the 21 st Century", Journal of Leadership Studies, Vol. 4, pp. 41-44.

\section{About the author}

Ivan Miloloža, Assistant Professor, Ph.D. graduated from the Faculty of Economics and Business in Zagreb and received a Ph.D. at the Faculty of Economics in Osijek in 2015. He is Assistant Professor at the Department of Dental Medicine and Health, Vice Dean for Institutional Cooperation and Development, and Chair of the Department of History of Medicine and Social Sciences. He has performed many social functions in various state bodies, associations, and banks and was a participant and guest lecturer at numerous domestic and foreign faculties and international conferences. The author can be contacted at ivan.miloloza@fdmz.hr 